\title{
Die Belydenis en vernuwing of hernuwing
}

\author{
HG van der Westhuizen
}

\section{VERBANDE}

Dit is nodig om perspektieflyne te trek waarin die Belydenis in historiese, kerkregtelike, dogmatiese en hermeneutiese verbande sy eietydse verband as ' $t$ ware self sal presenteer. Daarmee dink ek sal die volgende basiese vraag uiteindelik beantwoord moet wees: moet die Belydenis (vervat in al die bestaande belydenisskrifte van ons Kerk asook die belydenisskrifte self, miskien meer in besonder die Drie Formuliere van Enigheid) vernuwe en/of hernuwe word? Vernuwing van die Belydenis hou 'n verskeidenheid van moontlikhede in soos ekstensie, deduksie, revisie en substitusie van die belydenisskrifte. Hernuwing van die Belydenis hou in 'n herontdekking van die waarheid in die Belydenis, grondige kennis dus van die belydenisskrifte; aktualisering van die Belydenis.

'n Goue reël om altyd te onthou in die besinning oor die Belydenis is dat die Belydenis nie net van en vir teoloë alleen is nie maar van en vir die hele kerk. In hierdie verband sê Polman: 'De geloofsbelijdenis mag en moet niet zijn een belijdenis voor de theologen alleen, maar van de gehele gemeente. $\mathrm{Zij}$ behoort dan ook niet te zijn een wetenschappelijk geschrift, waarin de waarhede des heills op systematische en geleerde wijze worden uiteengezet. Wel moet zij zijn vrucht van studie en nadenken, maar de vorm en de wijze van uitdrukking behoort van die aard te zijn, dat zij is niet een wetenschappelijke uiteenzetting der leer, maar een belijdenis van het geloof der kerk, zoals zij het objectief vond in Gods Woord en subjectief heeft beleefd. Zo begint ook de Ned. geloofsbelijdenis met deze kenmerkende woorden: 'Wij geloven allen met het hart en belijden met de mond"' (1:551)

\section{OORSPRONG}

Die Belydenis is die kerk se gewete.

Hierdie intieme verhouding tussen kerk en Belydenis sê dat die kerk nie sonder die Belydenis ontstaan het nie en die Belydenis ook nie sonder die kerk nie (6:87). Ook "die stigting van die Hervormde Kerk in Nederland - aldus dr van Toornenbergen - val saam met die ontstaan van sy simbole of belydenisskrifte ..." (17:92). Die een sal 
sonder die ander nie homself wees nie. Die gedagtes van die kerk, wat hy vorm by die aanhoor van God se Woord en by die uitspraak daarvan in die verskillende verkondigingsgestaltes, vorm sy gewete. Wanneer hierdie gewete, die Belydenis, afgerond geformuleer word, is dié formulier' $n$ belydenisskrif.

Iemand wat voortdurend besig is om sy gesonde gewete te raadpleeg, doen dit integriteitshalwe onbewus en is konsensieus. Maar iemand wat gedurig besig is om sy gewete te wil herformuleer is sielsiek en onseker. Kerklik word dit ook geopenbaar onder andere in 'n voortdurende gebruik om uitsprake te maak in plaas van die Woord te spreek. "Eenuitspraak is zelden nodig en spreken meestal voldoende" (2:16). Tog moet die kerk, nie terwille van sy gesondheid of sy siekte nie, sy gewete eens formuleer. Dit terwille van sy nood. Die oorsprong van 'n belydenisskrif lê in die kerk se nood. Hierdie nood word deur 'n verskeidenheid van oorsake gevorm.

Eerstens moet gesê word dat die nood wat repeterend of duratief is, en reeds ' $n$ belydenisskrif tot gevolg het, die Belydenis aan die kerk gedurig prepresenteer. So is daar uit die verlede belydenisskrifte wat hul ontstaan mettertyd te danke het aan die noodsaak van belydenis by dope (Hand 8:37), belydenis in die erediens (Filip 2:6-11), belydenis teen die bose magte (Had 3:6, 12-16), belydenis voor vervolging ( 1 Kor 12:3; 1 Tim 6:12-16), belydenis teenoor dwaalleringe (1 Joh 4:2; 1 Kor 15:3-8). Uit hierdie oorsake soos van Niftrik Oscar Cullmann daaroor aanhaal (3:26-28), groei die Belydenis noodsaaklik (Matt 10:32-33) as antwoord op die vraag: "Maar julle ... wie, sê julle, is Ek?" (Matt 16:15). Breër gestel is die belydenis die antwoord van die kerk op die Woord van God (5:134). Dit is die antwoord op 'n gewetensvraag. Omdat Petrus se antwoord op Jesus se vraag so 'n grondwaarheid van die geloof formuleer, maak dit ook werklik nie saak dat alleen Matteus dit berig nie.

As daar in sekere omstandighede nog nie deur die kerk korrekte antwoorde gegee is op die vraag wie Jesus is nie, is dit noodsaaklik dat geantwoord moet word. Hierdie noodsaaklike antwoord of Belydenis vind sy skriftelike gestalte in ' $n$ belydenisskrif. ' $n$ Belydenis kom dus nie uit ' $n$ aanbod voort nie maar uit 'n aanvraag; dis nie ' $n$ gesogte saak nie maar 'n nood-saak $(4: 41,42)$. Die gehoorsame handeling van die Christen se lewe en die dissipline van die kerk, wat die dissipelskap van die kerk genoem kan word, word georden aan die hand van 'n kerkorde. 'n Kerkorde as die daad-like antwoord op die Jesus-vraag, vloei dus voort uit die Belydenis as die mondelinge en onmiddellike antwoord (7:61). Die noodsaak van Belydenis lê in die voorwaarde daarvan vir die lewe van die kerk. Wie aan die Belydenis van die kerk peuter moet weet hy krap aan die lewe van die kerk self. ' $n$ Kerk sonder ' $n$ belydenisskrif is 'n kerk sonder ' $n$ gegronde kerkorde: " ... omdat Calvyn self dié nadruk daarop lê dat 
die regte verkondiging van die Woord vanselfsprekend gevolg moet word deur die regte hoor van die Woord" (20:86).

\section{DOEL}

Die doel van die Belydenis lê opgesluit in sy betekenis, funksie en taak.

Die gewete van die kerk moet tot eer van die Heer van die kerk, wat die Hoof van die kerk is en die Geestelike impuls tot gewetesvorming gee, diensbaar aan die kerk as die liggaam van Christus wees.

Die belydenisskrifte formuleer die kerklike liggaam se gewete oor wat hy is, soos bepaal deur sy antwoord wie Jesus is. Die betekenis van die Belydenis lê daarin dat dit die bewussyn vorm van die kerk, die "persoonlikheid" van die kerk, die organiek van die kerklike organisme. En as sodanig het dit alles te doen met die eenheid van die kerk. Die kerk as die volk van God is 'n unieke volksorganisme van die herskepping wat midde in die volke (as organismes van die skepping), wat in sonde verval het, moet leef; leef met ' $n$ gewete. Hy word dus nie deel van die volk nie, staan ook nie bo of teenoor of langs of latent-onder die volke nie. Hy gaan in in die volke, in by die adresse van die mense, in die identiteite van mense in; maar hy mag nie sy gewete verloor nie - dan verraai hy Christus en pleeg selfmoord. Hy mag ook nie sy gewete verkrag nie, dan verloor hy homself, en verloën sy Heer. Die waarneembaarheid of sigbaarheid van die eenheid van die kerk vind dus in die eerste plek plaas in sy Belydenis. Buitekant die Belydenis eksisteer die kerk se eenheid nie tensy skisofrenies met 'n dubbele gewete. Die eenheid kom uit die Belydenis.

Die organisatoriese eenheidstrewe en die neiging tot hiërargie soos by Rome, hou blykbaar wedersyds verband met mekaar. Beide ontstaan vanuit 'n ekklessiologiese beskouing wat die kerk op sy baadjie takseer en nie op sy innerlike, sy gewete nie. Waar die eenheid organisatories gesien moet word, moet die opbouing van die organisasie voortgaan totdat ' $n$ hoof geïnstalleer is. Maar dan het 'n kop-oorplanting plaasgevind want die organiese Hoof van die kerk is Christus (Ef 4:12,15; 1 Kor 12:27). Die gewete van die kerk, minstens, moet so 'n vreemde orgaan verwerp. Enige kerk wat nie Christus as sy enigste Hoof erken nie, is 'n afkopkerk. "Egte ekumenisiteit sou dus daarin bestaan dat die gelowiges deur hierdie soeke na wat waar en reg is volgens die Skrif, op pad sal bly na die ekumene wat eenmaal aan die einde van hierdie aion tenvolle geopenbaar sal word wanneer geopenbaar sal word wie die kinders van God is (Rom 8:19-23)" (8:47). Vanweë die ekklesiologiese be- 
skouing van die Ned. Herv. Kerk van Afrika, is die belydenisskrifte van besondere belang.

Let egter daarop dat die unieke eenheid van die Belydenis nie geleë is in die numerieke een-heid van belydenisskrifte nie. Daarom kan die historiese gereformeerde Protestantisme ten spyte van vele belydenisskrifte (vanweë sy oppervlakte verspreidheid oor baie nasionaliteite heen) tog selfs 'n groter ooreenstemming met mekaar hê as byvoorbeeld die Lutherse Augsburgse konfessie van 1530 met die Lutherse Formulier van Eendrag van 1577. Die Dordtse Sinode kon van vele lande en kerke en belydenisskrifte byeen kom op grond van die substansie van die belydenisskrifte, die Belydenis, die gewete van die kerk. SP Engelbrecht haal JJ van Toornenbergen in hierdie verband aan: "De oude Gereformeerde reikten elkander op den inhoud der gezamentlijke belijdenis de hand, terwijl men het gemeenskappelijke geloof uitsprak. Niet om het uitwerken van dogmatische stellingen, maar om het credo, de substantie der leer die men beleed, was het te doen" (9:145).

Vanuit die belydenisskrif as beskrywing van die eenheid in die waarheid, vloei die funksie van die belydenisskrif voort. Dit is 'n simbool of vlag om die Christene van die Jode en die heidene te onderskei. Dit trek dus ' $n$ afgrensing tussen gelowig en ongelowig (vroeë kerk) tussen ortodokse geloof en kettery (laat vroeë kerk) tussen kerk en valse kerk (reformatoriese kerk) en tussen ware kerk en ware kerk (Lutherse en Calvinistiese kerk byvoorbeeld) - aldus AD Pont (18:240). Die vraag na 'n nuwe belydenisskrif genereer die vraag wat nou in- of uitgesluit moet word wat nog nie tot nou toe afgegrens is nie? Is die gees wat aandring op 'n nuwe belydenisskrif nie miskien die enigste waartéén 'n afgrensing weer moet plaasvind nie?

Hier wil ek graag ' $n$ voorbeeld noem van 'n poging tot 'n nuwe belydenisskrif, en wel van die Presbiteriaanse Kerk in Suid-Afrika (45):

We believe in God the Father, who created all the world, who will unite all things in Christ and who wants all people to live together as brothers and sisters in one family.

We believe in God the Son, who became man, died and rose in triumph

to reconcile all the world to God, to break down every separating barrier of race, culture or class, and to unite all people into one body. $\mathrm{He}$ is exalted as Lord over all, 
the only Lord over every area of men's life.

He summons both the individual and society,

both the Church and the State,

to seek reconciliation and unity between all

and justice and freedom for all.

We believe in God the Spirit,

the pledge of God's coming Reign,

who gives the Church power

to proclaim the good news to all the world,

to love and serve all people,

to strive for justice and peace,

to warn the individual and the nation of God's judgement

and to summon them both to trust the good news and obey Jesus Christ as King.

Watter tendens word in hierdie gegewe formulering bedoel? In dieselfde rapport word die tweede deel van die eerste strofe van die volkslied van die Republiek van Suid-Afrika (Ons sal antwoord op jou roepstem ens.) gekonstrasteer met: "The Gospel of Jesus Christ declares that Christ is our master ..." Die vierde strofe, en die perspektief wat dit gee ... knegte van die Allerhoogste ... is nie betrek nie! Die groot sonde waarteen die nuwe belydenisskrif blykbaar standpunt moet inneem, is "... the ideological heresy (in South Africa) that insists on the separate identity of racial groups ... The specific heresy which most acutely threatens the Church and its witness as well as society at this time in our country is the ideology of 'separate development'".

Die noodsaaklike funksie van 'n belydenisskrif, van onderskeiding, wat vandag ook aktueel 'n stuk verkondiging teen die universalisme van ' $n$ ongesonde ekumenisme is (40:62), hou 'n drieledige taak vir die kerk in, naamlik dat die onderskeidende waarheid kategeties aan die opkomende geslag tuisgebring sal word; polemies teen dwaalleringe in eie midde gestel sal word; missionêr aan alle mense bekend gestel sal word (10:12; 1:551).

Die doel van belydenisskrifte mond dus sterk kerkregtelik uit in die organiese betekenis daarvan, die afgrensende funksie daarvan en die evangeliese taak daarvan. Elke moontlike verandering aan die Belydenis sal in dier voege drievoudig reflekteer.

\section{WAARDE}

Die waarde van belydenisskrifte moet juis daarin gesoek word dat dit 'n sekureiteit bied teen onnodige refleksies op die gewete van die kerk. Die duiwel en listige mense probeer altyd om nie net self 
soos God en self God te wil wees nie, maar ook om aan die een kant hulle woord met God se Woord te koördineer indien nie te identifiseer nie, en aan die ander kant hulle standpunt of beskouing voor te hou as dié wat die kerk behoort te hê. Om die korporatiewe kerk nie uit te lewer aan die individuele gelowige en miskien selfs ongelowige nie, is die waarde van die belydenisskrifte daarin geleë dat dit die geloofsbeginsels oftewel die gewetenstruktuur van die kerk bevat. Twee verwysings na die Skrif onderstreep die waarde van die kerklike gewetenstruktuur: "Want doen tog navraag by die vorige geslag, en gee ag op wat hulle vaders nagespeur het; (want ons is van gister en weet niks nie, omdat ons dae 'n skaduwee op die aarde is;) sal húlle jou nie leer nie?" (Job 8:8 - 10 a; vgl 42:21). "Dit veral moet julle weet: geen profesie in die Skrif kan op grond van eie insig reg uitgelê word nie, want geen profesie is ooit deur die wil van 'n mens voortgebring nie" (2 Petr 1:21, 22).

Deesdae is een van die grootste sondes of onwetenskaplikhede blykbaar om van beginsels te praat: "Ons moet afsien van en afskeid neem van beginsels. Anders word ons Judaïste" (12:12). Dit is seker so dat te veel mense te veel dinge te veel geleenthede onveranderlike beginsels genoem het. Dit is nodig om weer eens te let op wat ds Joh Dreyer hieroor te sê had: "Kom ons nou by die uitdrukking 'in beginsel' is dit baie belangrik om te onthou dat die kerk nie so iets ken soos beginsels in die gewone sin van die woord nie. Die woord 'beginsel' is eintlik ' $n$ woord met ' $n$ onmiskenbare filosofiese herkoms. Daar dui dit byvoorbeeld 'n onveranderlike prinsiepe aan. Dit is egter ongelukkig so dat die kerk hom in sy spreke in die wêreld dikwels van filosofiese terme moet bedien ... Die kerk mag egter nooit die begrippe van die filosofie gebruik sonder om hulle vooraf te kersten, dit wil sê van 'n Bybelse inhoud te voorsien nie... Dus as die kerk nou wel soms die woord 'beginsel' gebruik ... (het dit) in die kerk altyd die betekenis van geloofsbeginsel ..." (38:11).

Dit is sekerlik ook so dat die Bybel nie die woord beginsel in ons gewone sin van die woord ken nie. Die Afrikaanse vertaling van die Nuwe Testament gebruik die woord "begin" of "oorsprong" vir archē "waar die Statevertaling dikwels beginsel" gebruik. In Judas 6 waar die Ou Afrikaanse Vertaling (OAV) nog "beginsel" vir archē het, het die nuwe vertaling (NAV) met "magsgebied" vertaal. Tog hou die woord archē in hierdie verband iets normatiefs in van "wesenlik", "outoritatief". In die begin lê die beginsel. So verwys Jesus, wanneer Hy oor die normatiewe in die huwelik spreek, na die archē daarvan (Matt 19:8) Die woord stoicheia wat in 2 Petrus 3:10, 12 in die OAV met "elemente" vertaal is en in die NAV met "hemelliggame", kan volgens die NAV se woordelys "die basiese elemente van die skepping (vuur, water, lug en aarde)" bedoel (11:576). Hierdie woord kry in Galate 4:3,9 en in Kolossense 2:8,20 die betekenis 
van "elementêre of voorlopige vorm van godsdiens (hier veral die Joodse godsdiens) wat nou nie meer betekenis het nie omdat Christus die volle openbaring gebring het" (11:577). Die OAV en die NAV vertaal in Galasiërs en Kolossense met "eerste beginsels van die wêreld". Dit het iets van die betekenis van die normatiewe, die essensie, die outoritatiewe, die prinsipe, die beginsel wat vir die betrokke instansie geld. In die geval waar beide behandelde woorde, archē en stoicheia, in die Nuwe Testament gekombineerd voorkom, Hebreërs 5:12, lui die NAV: "grondwaarhede (van die woord van God)". In Hebreërs 6:1 word archē in die NAV vertaal met die "eerste dinge (wat aangaande Christus verkondig word". Hierdie eerste dinge word deur dieselfde vers verder omskryf as die "fondament".

Daar is baie woorde wat voortdurend in die kerklike taal gebruik word wat nie in die Bybel voorkom nie. Dikwels kom 'n saak in die Bybel voor maar nie ' $n$ woord daaroor, of ons woord daarvoor nie. So 'n voorbeeld volgens prof A van Selms is "vaderlandsliefde" of "patriotisme" (13:166). Waarom sou ons vanweë die historiese en filosofiese inhoude van die woord "beginsel", die woord uit ons woordeskat verwyder terwyl dit 'n bruikbare draer kan wees van Bybelse fundamentele en grondwaarhede? Hierdie grondwaarhede van die geloof vind neerslag in die belydenisskrifte. Die Belydenis is die erkenning van en die aanvaarding van die gesag van die grondwaarheid van die geloof, dit is dat Jesus die Christus is en wat daarmee saamhang.

'n Grondwaarheid, 'n fundamentele waarheid, 'n beginsel, of die meervoud daarvan, figureer ook op alle lewensterreine van die mens. En as dit 'n grondwaarheid is behoort dit in alle soortgelyke situasies wat presies eenders is, eenders-geldend te wees. Maar soos die situasies verskil wissel die beginsel wat moet geld ook. In die geval van die grondwaarhede van die geloof behoort dit nooit te verander nie, omdat die situasie van die mens se sondigheid nooit verander nie. Juis omdat ons in 'n tyd leef dat "beginsels" van bakboord tot stuurboord oorboord gegooi word, is dit so belangrik dat die kerk sy belydenisskrifte ter hand sal neem en sy Belydenis ter harte.

Met die onveranderlikheid van die Belydenis slaan ons nog geensins die waarde van die belydenisskrif so hoog aan asof dit onveranderlik is nie. Waar die Belydenis nie uit ' $n$ mens is nie, maar deur God (Matt 16:17; 1 Kor 12:3), is die belydenisskrifte deur mense. Daarom sê Calvyn dat die Niceense bewoording "God uit God" battalogie of wartaal is (14:10). Teen hierdie agtergrond het Calvyn byvoorbeeld geweier om die Belydenis van Nicea te onderteken omdat die menslike bewoording van die waarheid van die drieeenheid in hierdie geval, nie die Belydenis is nie (15:42). Daar moet 
vanweë die menslike formulering van die kerklike belydenisskrifte die onderskeid-kapasiteit tussen die fundamentele en die nie-fundamentele in ' $n$ belydenisskrif erken word.

Uit hoofde van hierdie onderskeiding juis ontstaan intrakonfessionele verskille waarvoor in so ' $n$ mate ruimte gelaat moet word dat sommige meen dat 'n gravamen nie dáároor opgestel moet word nie (16:21). Verskille en gevolglike gravamen moet eerder gebaseer wees op die intensie en bedoeling van die Belydenis in die belydenisskrif as op allerlei swakhede en gebreke, soos byvoorbeeld swak formulering, swak Skrifverwysing, ensomeer (14:10). Ons kom later in 'n nadere verband op hierdie saak terug om iets oor die quia-quatenus saak te sê.

Voordat later oor die waarde van die belydenisskrifte gehandel sal word, moet nou eers in verband met die waarde van die Belydenis in die belydenisskrifte gevra word na die inhoud van' $n$ belydenisskrif.

'n Belydenisskrif is inderdaad nie ' $n$ "negosiekis waarin elke saak onder die son opgeneem moet word nie" (4:42). Dit is nie 'n Sjinese muur of brug vanwaar ' $n$ vyand beoorleg moet word nie, of ' $n$ museum waarin ' $n$ groot versameling ouderwetse rariteite te besigtig is nie (3:25). Dit is ' $n$ "oorsigtelike samevatting van die hoofpunte van die leerinhoud van die Bybel ..." (10:12). Soos reeds gesê was die kerk nooit sonder sy Belydenis en selfs belydenisskrifte nie - soos geformuleer in die belydenis van Petrus, Stefanus, die instellingswoorde van die nagmaal, die doopformule, ensomeer (18:239). Die historiese kern van die Belydenis is sekerlik te soek rondom die uispraak dat Jesus die Christus, die seun van die lewende God is (Matt 16:16). Ook waar aanduiding van die drieëenheid voorkom, soos in 1 Kor 12:4-6, is die historiese pit van die Belydenis: Jesus is die Here, afgrensend teen ' $n$ uitspraak: Jesus is ' $n$ vervloeking ( 1 Kor 12:3). Die Belydenis het histories uitgegroei soos ' $n$ organisme sodat die geskiedenis van die Belydenis die belydenis van die heilsgeskiedenis net omvattender gemaak het. Iemand kon dus sê dat die kortste omvattende prinsipiële kerkgeskiedenis in die Apostolikum te vind is. Elke bestaande belydenisskrif of moontlike nuwe moet nog steeds in essensie niks anders as die Bybelse inhoud van die bekende kerklike Belydenis bevat nie. In hierdie sin het ds MJ Goddefroy korrek gesê: Christianus mihi nomen; Reformatus cognomen. Ons is daarom ook nie Calviniste nie, maar Calvinisties Christene, soos die geestelike vader van die Heidelbergse Kategismus, keurvors Frederik de Vrome gesê het: "wij erkennen God lof dat wij christenen zijn, in Christus, en niet in Zwingli's, Calvyn's of Luther's naam gedoopt" (17:94).

Die wesenlike inhoud van die Belydenis moet tot in die jongste belydenisskrif dieselfde bly. Hierdie tendens bemerk ons histories ook inderdaad by die organiese uitbreidingsontstaan van die drie 
ekumeniese belydenisskrifte asook by dié van die Drie Formuliere van Enigheid. Die Dordtse Leerreëls is byvoorbeeld 'n uitbreiding van die Nederlandse Geloofsbelydenis art 16, terwyl die Heidelbergse Kategismus ook nie in inhoud nie maar wel in doelmatige vorm van die Ned. Geloofsbelydenis verskil (37:161).

\section{BINDING}

Basies is daar histories vier houdings teenoor ' $n$ belydenisskrif (19:33) wat ek wil noem konfessionegativisme, konfessionalisme, konfessio-relativisme en konfessionaliteit.

Met konfessionegativisme word die anabaptistiese houding bedoel wat eintlik elke belydenisskrif as ' $n$ ysterband van gewetensdwang sien en dit daarom verwerp. Hier word die Christen se gewete individueel bindend geag en die kerk se gewete verkrag.

Konfessionalisme wil weer op 'n Roomse wyse ' $n$ belydenisdwang toepas, gegrond op 'n verabsolutering van kerklike uitsprake. Die mensewoord in die kerk word gelyk gestel aan God se Woord: Roma Locuta, causa finita. Konfessionegativisme en konfessionalisme is beide humanisties. Die mensewoord word deur die een via die individu en deur die ander via die kerk gelyk gestel aan God se Woord.

Die konfessiorelativisme is histories hoofsaaklik die standpunt van die Arminianisme, die Remonstratisme. Dit is die standpunt waar die individuele gewete én die kerklike gewete erken word maar eersgenoemde onmiddellike gesag toegeken word en laasgenoemde, soos in die belydenisskrif vervat, 'n potensiële gesag. Hier word die Belydenis op individuele gesag onderskei en geskei van die belydenisskrif $(16: 12)$. Omdat die tendens tot vernuwing van belydenisskrifte en tot die opstel van 'n nuwe belydenisskrif, sterk ooreenkomste vertoon met die konfessiorelativisme, sal ons na hierdie standpunt in die bespreking later terugkom.

Die gereformeerde reformatoriese standpunt van konfessionaliteit sien die belydenisskrif as ' $n$ kort herhaalde formulering van die Woord van God en daarom bevat dit ' $n$ vaste maatstaf vir die geloof, leer, lewe en prediking. Hier is dus ook sprake van 'n relatiwiteit, maar nou nie in my verhouding tot die belydenisskrif nie, maar in die verhouding van die belydenisskrif tot die Heilige Skrif (5:134; 16:20).

Vanweë laasgenoemde onderskeiding kom die probleem na vore of 'n leraar van 'n kerk hom met sy handtekening aan sy kerk se belydenisskrifte of aan sy kerk se Belydenis verbind? By die houding wat ons konfessionaliteit genoem het, kan daar geen sprake wees of 'n leraar of ' $n$ ander lidmaat nie aan die Belydenis verbind is nie. 
Maar is hy net daaraan verbind of ook aan die Belydenisskrif? Wat is die verhoudig Belydenis: belydenisskrif?

Dit bring ons by die quia-quaenus saak. Omdat die Belydenis tog nie anders as geformuleer kan wees nie, net soos 'n gewete nie sonder ' $n$ aanspraak kan wees nie, moet die belydenisskrif ernstig opgeneem word. En omdat die bedoeling van die belydenisskrif behoort te wees om in ooreenstemming met die Heilige Skrif te wees - omdat die belydenisskrif ooreenkom met die Heilige Skrif. Die belydenisskrif is ' $n$ norm, 'n genormeerde norm - norma normata. Maar dit is nie 'n norm naas die Heilige Skrif nie, maar vanweë die Heilige Skrif - die norma normans. Omdat die belydenisskrif die Belydenis wil formuleer, en laasgenoemde soos die Heilige Skrif uit God is, terwyl eersgenoemde uit die kerklike mens is, is die moontlikheid van verskil tussen Belydenis en belydenisskrif nog altyd daar en is die onderskrywing van die belydenisskif quatenus - sover dit met die Heilige Skrif ooreenkom. Die binding is dus nie ongekwalifiseerd quia of quatenus nie, maar gekwalifiseer quia én quatenus (14:11). Jy is gebind maar nie verbind nie. "As ons quia alleen sê, beteken dit soveel as: die formuliere is ' $n$ feillose weergawe van die Skrif, wat sou beteken dat ' $n$ gravamen uitgeslote is. Daarom met ons eintlik sê: quia en quatenus. ... Tussen verstarring en verwarring sal ons alleen dán veilig deurstuur as die Reformatoriese sola Scriptura die leuse bly. Ons is nie én aan die Woord van God én aan die belydenis gebind nie. Die belydenis bind ons juis aan niks anders as die Woord van God nie en verbied elke ander binding (art 7. NGB). Alleen omdat en in sover die belydenis dit doen, bind dit ook ons (Plomp in Geref Weekblad, 21 Des 1962). Dit was trouens ook die standpunt van die Dordtse Sinode, wat almal wou bind 'non ulla scriptura humana sed solum Dei Verbo' (vgl Polman in Geref Weekblad, 11 Nov 1963) ... Onder biddende opsien tot God, en met inagneming van sowel die Scylla van verstarring as die Charybdis van verwarring, kan die kerk van Christs in hierdie apokaliptiese tyd 'n helder geluid laat hoor, kontinu met die kerk van alle eeue, maar ook aktueel vir die tyd waarin ons lewe" $(41: 79,80)$.

Die quia-rede gee dus nog nie die reg om die atmosfeer van die geregshof om die belydenisskrif te hang nie, waar almal wat met die swakheid van die belydenisskrif probleme het opgevorder moet wees nie. Die quatenus-rede maak die kerk redelik. Maar die quatenus-rede bied nogtans die voorreg om die geur van die brandstapel aan die Belydenis in die belydenisskrif te verbind $(17: 94 ; 16: 24)$. Die historiese ondertekeningsformulier sedert Dordt 1619 (37:170), formuleer dan ook so om te wil sê: omdat ... derhalwe (18:174).

Die ondertekening, ' $n$ heilige eed (21:233) bind die belyer met die Belydenis soos dit op daardie oomblik geformuleer is (18:242; 33:11, 18). Met hierdie geformuleerde gewete luister die leraar eksegeties 
verder na die Woord van God. Daarmee is uitdruklik nie gesê dat die Woord onder die gewete staan nie, maar wel dat ek met my kerklike gewete onder die Woord staan. "Daarom eksegetiseer ek nie die Heilige Skrif in die lig van die Drie Formuliere van Enigheid nie, maar staan onder die Wood alleen - saam met Calvyn (IV, 9,8) ... En sodra my eksegese ander resultate as die belydenis oplewer, weet ek dat ek na alle waarskynlikheid verkeerd geëksegetiseer het, en probeer weer - nie net tien maal nie, want ek is baie dommer as Van Niftrik. Maar prinsipieel bly die moontlikheid oop dat die belydenis foutief is. Daarom is dit my plig om - indien ek uiteindelik nie in die belydenis die Heilige Skrif kán hoor nie - gravamen in te dien, 'want de Woord des Heren alleen heeft gesag over de consciëntie'" (42:29). Sou iemand van die Belydenis verskil is die gravamen die kerkregtelike weg. Nie die begrawing van die belydenisskrif nie (18:243; vgl. ook 22:66-83). Die leertug moet uitgeoefen word. Dit is net ' $n$ vraag of die proses nie van die kerkwet as beginpunt in praktyk terug geskuif moet word na die belydenisskrifte as praktiese beginpunt nie. Leertug is nie die derde kenmerk van die kerk (waarmee die kerkorde te doene het) nie. "De leertucht ... ligt immers reeds besloten in het eerste, de rechte prediking des Woords" (2:5). Miskien moet met die oog op die regte prediking van die Woord meer aandag deur predikante aan die Belydenis gegee word as om maar hoofsaaklik die saak aan die kerkwet en die ouderlinge oor te laat. "Calvijn zegt in zijn Institutie, dat de predikanten de schapen moeten weiden en de wolven doden. In de Londense liturgie staat dat, meen ik, ook nog. In bovengenoemde formulier (Bevestigingsformulier vir Ouderlinge en Diakens, anoniem ontstaan in \pm 1586 ) echter zijn de ouderlingen de herders geworden en de predikanten als mogelijke wolven genoemd" (2:14). Met die oog op wat die eerste reformatoriese praktyk in verband met leertug was, haal ek as voorbeeld die Geneefse Kerkorde van 1561 aan: " 20 Nou, soos dit noodsaaklik is om die dienaar vóórdat hy gekies word sorgvuldig te toets, so moet daar ook 'n goeie ordening wees om hulle by hulle plig te hou. Daarom sal dit in die eerste plek nodig wees dat alle dienaars, met die doel om die suiwerheid van en die ooreenstemming ( = concorde) met die leer te bewaar, elke week op 'n bepaalde dag sal saamkom vir ' $n$ bespreking van die Skrif en dat niemand sonder ' $n$ wettige verskoning afwesig sal wees nie. Indien iemand nalatig is, sal hy vermaan word" (18:25). Vervul ons predikante broederkringvergaderings, die predikantevergadering en die moderne mediakommunikasie hierdie funksie kerkregtelik effektief?

\section{REVISIONISME}

Dit is ' $n$ natuurlike reaksie dat ' $n$ belyer (De martelaren der oude 
Kerk werden Confessores, Belijders, genoemd - 3:23) wat van die belydenisskrifte verskil, die belydenisskrifte wil verander. Maar vandag lewe ons in ' $n$ tyd wat algemeen getipeer kan word as ' $n$ tyd waar die gees van verandering soos 'n bose gees vaardig is.

Die moderne gestaltes van die koors van die woelsieke libertynse loskoppe (23:101) wat revisionisties soos die remonstrantisme aan konfessiefobie ly (16:24), moet klinies by die konfessiorelativisme ingedeel word. Die sogenaamde mondige mens van vandag wil in ieder geval op humanistiese wyse ten opsigte van die belydenisskrifte negativisties, relativisties of outokonfessionalisties vry-sinnig wees. Maar die mondige mens, ook van die nuwe teologie, is die teenoorgestelde as die sondige mens wat baie duidelik in ons reformatoriese belydenisskrifte ten voete toe uit geskilder is.

Die onreformatoriese antropologie is natuurlik in die nuwe teologie moontlik vanweë 'n Skrifbeskouing wat nie met ons belydenisskriftelike Skrifbeskouing korreleer nie. Wolfhart Pannenberg is "een van die leidende figure in die nuwe teologie" (24:93). Hy sien korrek die openbaring van God as histories maar onreformatories sien hy die geskiedenis feitlik ongekwalifiseerd as openbaring (25:213). In hierdie opsig is HM Kuitert baie naby aan Pannenberg se beskouing. Hy sien die Bybel as 'n stuk tradisie hoe mense vroeër God se spore en tekens in die geskiedenis ondek het. Ons sou dan nie op grond van die Bybel kan glo nie, maar op grond van die kumulatiewe insig en ervaring in die historiese vlegwerk van God se dade. Daarom sien hy die Nuwe Testament as die bystelling van die Ou Testament (26:3-20). Die verbum externum-openbaringsbeskouing sien Kuitert as "inbraak" in ons wêreld (26:17). En so moet die voortgaande teologie en gepaardgaande belydenisskrifte as bystellende en voortgaande openbaring gesien word. As derde en laaste voorbeeld, $\mathrm{H}$ Berkhof: "De openbaring is nog niet voltooid en ons kenne is dus ook fragmentarisch. Elke geloofsleer is daarom een gedateerde momentopname' (30:39). Die begrip kanonisiteit van die Bybel word natuurlik in die gedrang gebring. Hierdie keer word die belydenisskrif nie op een lyn met die Heilige Skrif geplaas nie, maar die Heilige Skrif op een lyn met die belydenisskrif. Wat is die verskil? In albei gevalle bevat die Bybel slegs 'n gerelativeerde waarheid met géén gesagsaanspraak op die mens nie (31:16). Die Calvinistiese tota Scriptura en sola Scriptura (31:10) word totaal-en-al verteer. Die gewetevormer is ook die gewete-aanspraak. Kanonvasstelling is gewete-aanspraak-erkenning. Die gewetevormer, die Heilige Gees met die Heilige Skrif laat niks meer of minder of anders die gewete-aanspraak wees nie. Die kanonvasstelling kan nie heeltemal die eerste geloofsbelydenis van die oudste Christelike kerk genoem word nie $(43: 11 ; 44: 31)$, omdat dit nie soseer'n antwoord op die gewete-aanspraak is nie as ' $n$ besefmededeling van wat as gewe- 
tevormer verneem is. Hierdie nuwe teologie met die tendensieuse humanisering van die teologie wat die metafisese substitueer met die sosiaal-politieke (39:88), mond uit die leer van die anonieme Christen (28:86) waar verkondiging volledig met dialoog vervang word (29:12).

Teen hierdie agtergrond het die sewentiende-eeuse gees van remonstrantse revisionisme $(16: 23 ; 23: 101)$ herleef $(34: 22 ; 35: 8)$. Dit is wel waar dat die belydenisskrifte as menslike geskrifte (NGB 7) "examinabel" is, maar die Belydenis is nie "revisionabel" nie (23:100). Die reformasie het in beginsel die voortdurende hervorming gestel (35:8). Ons mag nie die belydenisskrif vanuit ' $n$ konfessiomesmerisme beskou as managelaai of Goddelik geïnspireer nie. Tog beteken die reformatoriese beginsel van "ecclesia reformata semper reformanda est Verbo Dei" geensins dat die kerk oor sy belydenisskrifte in 'n "voortdurende onrus" moet wees nie (16:23). Om 'n saak in die lig van die Skrif as siek te mag en moet diagnoseer is reformatoriese lewensbeginsel. Om op' $n$ saak tot siekwordens toe te eksperimenteer om te kyk of dit nie dalk al vanweë die veranderde Skrifbeskouing 'n gedaanteverwisselingsoperasie kan ondergaan nie, is onvergenoegde vitterigheid - dikwels onder die voorwensel van wetenskaplikheid.

Wanneer die kerk die bestaande belydenisskrifte langs geordende wyse as dubbelsinnig, onvolledig en onvoldoende bevind (1:552), of as inkongruent aan die tyd (Kommunisme, Ekumenisme, ideologieë, Swart Teologie, ensomeer) of die plek, byvoorbeeld op die sendingveld (7:62) waar byvoorbeeld in Afrika 'n Confessio Africana nodig kan wees (36:300), moet daar sekerlik aan die belydenisskrifte of aan 'n belydenisskrif aandag gegee word. Dit moet egter nie gedoen word voordat daar nie deeglik rekenskap van gegee is of dieselfde sake nie onder ander terme reeds in die belydenisskrifte gedek is nie.

Twee dinge is belangrik. Die bestaande belydenisskrifte moet hernuwend van die verbondskinders af tot die verbondsteoloë toe, geaktualiseer word (27:16). Dán sal nuwe geeste beter onderskei en beproef kan word, en dalk meermale geïdentifiseer kan word as bose oues in verligte teologiese engele kledy (1 Joh 4:1; Gal 1:8; 2 Kor 11:14).

\section{Verwysings}

1. POLMAN, ADR: Belijdensschrift in Christelijke Encyclopedie, JH Kok NV Kampen, Deel 1, 1956.

2. NOORDMANS, O: Instituut en volk, H Veenman \& Zonen, Wageningen, 1952.

3. VAN NIFTRIK, GC: Kleine Dogmatiek, Callenbach-Nijkerk, 1953. 
4. DE WET, JI: 'n Nuwe belydenis as, "akkoord van gemeenskap" tussen die Afrikaanse kerke, in Van der Hoff-blad, 1973.

5. MANS, CJ: Die verhouding van belydenis en kerkorde, in Hervormde Teologiese Studies, Jg 28 (3 en 4).

6. JONKER, WD: Die onvervangbare verlossingsboodskap, in Kerk en Wêreld 1978, Sendingpers, Bloemfontein, Jan 1979.

7. VAN DER WESTHUIZEN, HG: Volkskerk en Sending, HAUM, 1981.

8. DE WET, JI: Die leer van die kerk, in Hervormde Teologiese Studies, Jg 21 (2 en 3).

9. ENGELBRECHT, SP: Die Heroormde Konfessies, in Heroormde Teologiese Studies, Jg 2 (4), Jan 1946.

10. ENGELBRECHT, BJ: 'n Nuwe ekumeniese geloofsbelydenis (II), in Die Hervormer, Augustus 1981.

11. Die Nuwe Testament en die Psalms, 1979-vertaling met woordelys en teksverwysings, Bybelgenootskap van Suid Afrika.

12. GODSCHALK, LAF: Bybel, Filosofie en Praktyk, in Die Wagter, Gereformeerde Blad, Jg 3 (9), September 1981.

13. VAN SELMS, A: Vaderlandsliefde in Oud-Israel, in Hervormde Teologiese Studies, SP Engelbrecht-jubileum nummer, Oktober 1946.

14. POLMAN, ADR: De Autoriteit van de Belijdenis, in In die Skriflig, Jg 7 (27), September 1973 .

15. ENGELBRECHT, SP: Die Hervormde Konfessies II, in Hervormde Teologiese Studies, Jg 3 (1 en 2), Junie 1946.

16. COETZEE, PJ: Die Binding van die Konfessie, in In die Skriflig, Jg 4 (16), Desember 1970.

17. ENGELBRECHT, SP: Die Nederlandse Geloofsbelydenis as simboliese geskrif $I$, in Hervormde Teologiese Studies, Jg 2, Februarie 1944.

18. PONT, AD: Die Historiese Agtergronde van ons Kerklike Reg, Deel I, HAUM, 1981.

19. SMITH, DJ: Die aktualiteit van Nicea, in Hervormde Teologiese Studie, Jg 32 (1 en 2).

20. PONT, AD: Skrif en Kerkorde - enkele opmerkings, in Hervormde Teologiese Studies, Jg 33 (1 en 2).

21. VISSER, LLJ: Die aktualiteit van die Dordtse Leerreëls, in Ned Geref Teol Tydskrif, Sept. 1968.

22. PONT, AD: Die Kerkwet en die amp van die dienaar van die Woord, in Hervormde Teologiese Studies, Jg 17 (2, 3 en 4), Des 1961.

23. POLMAN, ADR: Onze Nederlandsche Geloofsbelijdenis, Eerste deel, T Wever-Franeker, sj.

24. DU PLESSIS, I]: Wolfhart Pannenberg en die opstanding, in Ned Geref Teol Tydskrif, Maart 1972.

25. VAN HUYSSTEEN, JWV: Die Geskiedenis - teologie van Wolfhart Pannenberg, in Ned Geref Teol Tydskrif, Jg 15 (57), Maart 1981.

26. BREMMER, R: De Hermeneutische Theologie van HM Kuitert, in In die Skriflig, Jg 15 (57), Maart 1981.

27. ENGELBRECHT, BJ: ' $n$ Nuwe ekumeniese geloofsbelydenis (III), in Die Hervormer, September 1981.

28. KÖNIG, A: Die leer van die Anonieme Christen, in Ned Geref Teol Tydskrif, Maart 1969.

29. KURPERSHOEK, WL: Dialoog of Verkondiging, in In die Skriflig, Jg 15 (58), Junie 1981.

30. BERKHOF, H: Christelijk Geloof, Uitgeverij GF Callenbach, BV - Nijkerk, 1973.

31. NAUDE, JP: Die soeke na 'n verantwoordelike Skrifbeskouing, in Die Hervormer, November 1981.

32. ENGELBRECHT, BJ: Calvyn en die Calvinisme, ongepubliseerde lesing voor die predikantevergadering van die NHKA, 1981.

33. PONT, AD: Kerk en Struktuur, ongepubliseerde lesing voor die predikantevergadering van die NHKA, 1981.

34. VAN WYK, JH: Die vraag na 'n nuwe belydenisskrif, in In die Skriflig, Jg 8 (32), Des 1974.

35. ENGELBRECHT, BJ: 'n Nuwe ekumeniese geloofsbelydenis? in Die Heroormer, Julie 1981. 
36. OOSTHUIZEN, GC: Die Godsdienste van die Wêreld, NG Kerkboekhandel, 1978.

37. ENGELBRECHT, SP: Die Heidelbergse Kategismus as Kerklike Simbool, in Heroormde Teologiese Studies, Aflewering 4, Augustus 1944.

38. DREYER, JOH: In beginsel of in die praktyk, in Die Heroormer, Januarie 1974.

39. GRAAFLAND, C: Theologische Hoofdlijnen, in Gij die eertijds verre waart ..., BV Uitgeverij De Banier, Utrecht, 1978.

40. VAN DER WESTHUIZEN, HG: Ekumenisme, in Die Hervormde Teologiese Studies, $\mathrm{Jg} 36$ (3 en 4).

41. DU TOIT, S: Tussen Vestarring en Verwarring, Tradisie-Belydenisskrif, in Ned Geref Teologiese Tydskrif, Maart 1965.

42. KÖNIG, A: Die Heilige Skrif en die Drie Formuliere van Enigheid, in Ned Geref Teologiese Tyskrif, Januarie 1966.

43. FLOOR, L: Die Neo-Marxisme in die teologie-Teologies beoordeel, IBC-studiestuk 166, Potchefstroom, Oktober 1981.

44. LOHSE, B: Epochen der Dogmengeschichte, Kreuz-Verlag-Stuttgart, 1963.

45. BAX, DS: Church and Nation (South Africa) Report 1981. 